\title{
Social and Economic Development - A Rights Puzzle
}

\section{Pervez Tahir and Sara Fatima*}

Everyone has the right to a standard of living adequate for the health and well being of himself and of his family, including food, clothing, housing and medical care and necessary social services, and the right to security in the event of unemployment, sickness, disability, widowhood, old age or other lack of livelihood in circumstances beyond his control. Article 25.1 of the Universal Declaration of Human Rights, 1948.

States should undertake, at the national level, all necessary measures for the realization of the right to development and shall ensure, inter-alia, equality of opportunity for their access to basic resources, education, health services, food, housing, employment and the fair distribution of income. Effective measures should be undertaken to ensure that women have an active role in the development process. Appropriate economic and social reforms should be carried out with a view to eradicating all social injustices. Article 8.1 of Declaration of the Right to Development adopted by the General Assembly Resolution 41.28 on 4 December 1986.

The torture of a single individual raises unmitigated public outrage. Yet the deaths of more than 30,000 children a day from mainly preventable causes go almost unnoticed. Human Development Report 2000.

\section{Introduction}

During the seventies and the eighties, Pakistan experienced a steady decline in the percentage of the population below the caloric poverty line. This trend began to reverse around 1993-94 and has continued to deteriorate since. At the end of the decade, tentative official estimates put the proportion of the poor at 29 per cent. Traditionally the civil society's struggle for rights in Pakistan, particularly in the early decades, was limited to workers' rights. In recent years, a stronger civil society movement has centred around civil and political rights. It is puzzling to see social and economic rights on the back burner at a time when every third Pakistani is eking out an existence below the poverty line.

\footnotetext{
* Dr. Pervez Tahir is Chief Economist, Planning Commission, Government of Pakistan and Ms. Sara Fatima is a Development Professional. The authors thank Mr. Reza Ali for useful comments on an earlier draft. Views expressed here are personal and do not reflect any institutional affiliations.
} 
Two major reasons for this are apparent. First, the global focus of the human rights movement on civil and political freedoms, and, on issues related to minorities and marginalised groups. Across the globe the focus of the human rights movement has been on the establishment of a legal and constitutional framework that allows citizens to enjoy and exercise civil and political rights. The United Nations Charter for Human Rights - based on the premise of the indivisibility of human rights - included a Covenant on Socio-Economic and Cultural Rights. Western democratic states at the time of the ratification of the Charter were able to ensure civil and political freedom in their countries; the communist bloc in turn sought to ensure social and economic rights in theirs. A balance making both sides happy was reached in the Charter. This is not reflected in the movement itself. The human rights discourse was grounded in the western democracies, the focus was on lobbying for civil and political rights in the non democratic, communist, and developing countries; lobbying for social and economic rights got inextricably linked to the politics of the socialist and communist regimes; no absolute values were allowed to emerge.

Secondly, the path to attaining socio-economic rights is less clear and more complex; no 'model' is better in absolute terms than another, the level of social economic rights is perhaps more relative and part of a continuum, and central to achieving these is public choice: determining strategies, principles and resource allocation priorities through a political process. Arguably, any State working towards job creation, the delivery of basic social and municipal services and shelter is working towards the social economic rights of its people. These objectives can be arrived at differently by different types of governments and by different political processes. There is no blue-print to follow.

The international community has responded to this by avoiding the issue of absolute social and economic rights. Instead it has, through international agencies and in consultation with governments, established 'targets' and sought consensus on principal processes for their attainment. Donor conditionality reflects this under the rubric of human development.

In this paper we look briefly at two aspects of social and economic rights in Pakistan. One, what the state's responsibilities and commitments vis a vis social and economic rights are. In order to do this we look at the rights enshrined in the Constitution; the commitments made to international donor agencies; and the laws related to various levels of government. Two, we review the State's success in the delivery of these rights. We find an unenviable gap between promise and performance and conclude that further work is required to resolve the tension between civil and political rights on the one hand and social and economic rights on the other. 


\section{The Constitution and Social and Economic Rights}

The State under the Constitution of Pakistan is not made responsible for the attainment of Social and Economic Rights for its citizen; it also does not give any system of redressal for the attainment of these rights. As set out in the Constitution, the National Economic Council, has responsibility for the formulation of social economic plans and programmes which are then reflected in the Medium Term and Annual Development Programmes/Plans of the Government. The National Economic Council is guided by the principles of policy when formulating these plans. Chapter 2 of Part II of the Constitution states:

29. (2) In so far as the observance of any particular Principle of Policy may be dependant upon resources being available for the purpose, the Principle shall be regarded as being subject to the availability of resources.

30. (2) The validity of an action or of a law shall not be called in question on the ground that it is not in accordance with the Principles of Policy, and no action shall lie against the State, any organ or authority of the State or any person on such ground."

The Constitution, however, after ensuring that the State, or any of its bodies, can not be held accountable in a court of law, does make the State responsible for certain social and economic rights. Chapter 2 of Part II of the Constitution states:

34. Steps shall be taken to ensure the full participation of women in all spheres of national life.

35. The State shall protect the marriage, the family, the mother and the child.

37. The State shall:

a. promote, with special care, the educational and economic interests of backward classes or areas;

b. remove illiteracy and provide free and compulsory secondary education within minimum possible period;

c. make technical and professional education generally available and higher education equally accessible to all on the basis of merit;

d. ensure inexpensive and expeditious justice; 
e. make provision for securing just and humane conditions of work, ensuring that children and women are not employed in vocations unsuited to their age or sex, and for maternity benefits for women in employment;

f. enable the people of different areas, through education, training, agricultural and industrial development and other methods, to participate fully in all forms of national activities, including employment in the service of Pakistan;

g. decentralise the Government administration so as to facilitate expeditious disposal of its business to meet the convenience and requirements of the public.

38. The State shall:

a. secure the well being of the people, irrespective of sex, caste, creed or race, by raising their standard of living, by preventing the concentration of wealth and means of production and distribution in the hands of a few to the detriment of general interest and by ensuring equitable adjustment of rights between employers and employees, and landlords and tenants;

b. provide for all citizens, within the available resources of the country, facilities for work and adequate livelihood with reasonable rest and leisure ;

c. provide for all persons employed in the service of Pakistan or otherwise, social security by compulsory social insurance or other means;

d. provide basic necessities of life, such as food, clothing, housing, education, and medical relief, for all such citizens, irrespective of sex, caste, creed or race, as are permanently or temporarily unable to earn their livelihood on account of infirmity, sickness or unemployment;

e. reduce disparity in the income and earnings of individuals, including persons in the various classes of the service of Pakistan."

Taking a cue from the UN conference on Human Environment held in 1972 in Stockholm, the Constitution of 1973 recognised the subject of 
"Environmental Pollution and Ecology" and placed it on the concurrent list. The right to a clean environment was not identified.

\section{State Institutions Responsible for Social and Economic Rights}

If citizens in Pakistan can not go to a court of law for the delivery of social and economic rights they have only two other avenues: one, through a political process hold politicians accountable for these rights and, two, hold institutions, established under statutory or corporate law, accountable.

The political process of accountability has been fraught with many factors. Apart from the fact that the democratic process in general has been discontinuous, a functional differentiation of local politics, provincial politics and national politics has not emerged due to the tendency to centralise all state functions. If, for instance, one level of government, the local level, had been responsible for certain elements of social and economic rights - such as municipal services - it could have been held responsible for the delivery of primary education, primary health, reproductive health, water and sanitation through both political and institutional systems; provincial politicians could in turn have been held responsible for higher levels of education and health services, shelter, and the environment; and national politicians for poverty, employment and growth.

Chapter 2 of Part II of the Constitution states that: "32. The State shall encourage local Government institutions composed of elected representatives of the areas concerned and in such institutions special representation will be given to peasants, workers and women." Thus the Constitution does not make it obligatory on the State to constitute local governments. Citizens have no clear avenue for redressal for the elements of social and economic rights which would normally come under the purview of local governments.

The Constitution is, however, clearer, on the functional responsibilities between the Federation and the provinces. The major issue in this is also an overlapping of functions and the centralisation by the Federation of functions that are not on the concurrent list. The concurrent list was to be reviewed subsequently, but was not.

For example, if a citizen anywhere in Pakistan, would like to take a State institution to task for the delivery of education it would in its own constituency find federal, provincial and local government institutions responsible for the same service. Outside of a political process of accountability at the federal and provincial levels, which includes a basket of several types of goods and rights, and the infrequency of local government 
elections, citizens can only turn to statutory bodies or corporate bodies for redressal.

Urban local councils and District councils under the 1979 Local Government Ordinance, and Water and Sanitation Agencies and Boards, are responsible for basic municipal services; a number of autonomous educational and health institutions under their respective charters are responsible for higher education and health care like Universities, etc. These institutions have been guided by a set of government policies. However, given the inherent inefficiencies in the system, the control of funds primarily at the provincial and federal levels, these independent institutions have been ineffective in terms of service delivery. Concerned citizens, at the local level, have taken these institutions to court; both on procedural grounds and on effectiveness of service delivery. These cases have not entered the mainstream of the discussion on social and economic rights, or, increased pressure on institutions to improve service delivery.

\section{Commitments to the International Community's Development Targets and Major Charters and Covenants}

The international community, under the auspices of the United Nations, has established international targets related to social and economic rights. These targets are translated into actual programmes through member State's national policies and priorities of international financial organisations and donors. The international financial organisations and donors enforce these in turn through a number of strategies; priorities for resource allocation; conditionalities on member states; and through major campaigns, particularly, bringing specific rights into focus through the declaration of 'decades', 'years' or 'days'. The latest international poverty reduction targets set by the international community for 2015 are given at Annex-I. The major covenants and charters in the social and economic sectors, and Pakistan's positions vis a vis them, are given in Annex II. Pakistan has a long distance to cover on the road to international development targets. The road map is characterised by commitments exceeding actions. Annex III shows that Pakistan lags behind India and Tajikistan on the Human Development Index. Annex IV outlines the challenge ahead.

\section{The State of Social and Economic Rights}

Pakistan is among the few countries of the world which does not have an officially determined and monitored poverty line. There is no dearth of studies by individuals and institutions, each adding to the problem of discerning a trend. Information on unemployment conflicts with daily experience, mainly because of the reporting problems. Data problems in social 
sectors are no less intractable, despite the plethora of donor-funded 'information management systems' in nearly all sectors. The discussion that follows on the state of social and economic rights keeps these informational inadequacies in view.

\section{(a) Poverty and Unemployment}

The average income of the poorest households in 1998-99 was Rs. 1500 per month. Of this income the household was utilising 54 per cent of its income on food - Rs. 810 - an insufficient amount to meet the daily caloric requirement. The low proportion of expenditure on food could be due to the high proportion of income that has to be spent on services and utilities. The income of perennial industrial workers was less than double (Rs. 2750) this amount. Table 1 gives an idea of the proportion of the poor under the poverty line over time.

Table-1: Poverty Trends

(\%)

\begin{tabular}{lccc}
\hline \multicolumn{1}{c}{ Years } & Total & Rural & Urban \\
\hline $1986-87$ & 26.9 & 29.4 & 24.5 \\
$1990-91$ & 23.3 & 26.2 & 18.0 \\
$1992-93$ & 20.3 & 22.5 & 16.8 \\
$1993-94$ & 20.8 & 24.4 & 15.2 \\
$1999-2000$ & 28.7 & 29.3 & 27.6 \\
\hline
\end{tabular}

Source: Government of Pakistan, Planning Commission, Poverty Reduction Programme 2001-04.

The poor in Pakistan are characterised by certain features: Firstly, poverty is concentrated in certain geographical locations; secondly, nearly 35 per cent of poor households have household heads with no formal education; thirdly, nearly 30 per cent of poor households are headed by people who are older than 50 years of age; fourthly, households are more likely to be poor if they are employees and not employers, households in the agriculture and manufacturing sectors are more likely to be poor than households in trade, services and utilities; and fifthly, the larger the size of the household the more likely that it will be poor.

Moreover, although scant attention is paid to this factor, urban poverty in Pakistan is also on the increase. A significant portion of the urban 
population lives in areas outside municipal boundaries with little access to services. Nearly 35-50 per cent of the urban population lives in slums and under-serviced areas. By 2015 the urban population in Pakistan will exceed the rural population. The incidence and depth of poverty by type of households is given in Table- 2 .

Table-2: The Burden Incidence of Poverty (\% of Households)

\begin{tabular}{lcccc}
\hline & \multicolumn{2}{c}{ Incidence } & \multicolumn{2}{c}{ Depth } \\
\hline & Rural & Urban & Rural & Urban \\
\hline Asset Ownership & & & & \\
Owning no property & 50 & 29 & 14 & 6 \\
Owning property & 31 & 27 & 8 & 6 \\
Owning Livestock & 21 & - & 5 & - \\
Educational Attainment & & & & \\
Illiterate & 36 & 40 & 9 & 9 \\
Primary & 33 & 34 & 8 & 7 \\
Higher Secondary & 17 & 17 & 3 & 3 \\
Graduate/Post-Graduate & 14 & 4 & 3 & 1 \\
Employment Status & & & & \\
Unemployed & 33 & 22 & 8 & 3 \\
Under employed wage earners & 42 & 30 & 11 & 6 \\
Self Employed & 27 & 25 & 6 & 5 \\
Transfers & & & & \\
Household w/o transfers & 34 & 28 & 8 & 6 \\
Households with transfers & 26 & 26 & 6 & 6 \\
Receiving remittances & 23 & 22 & 6 & 4 \\
-outside Pakistan & 12 & 12 & 2 & 1 \\
-inside Pakistan & 25 & 6 & 6 \\
$\quad$-Zakat beneficiaries & & 61 & 17 & 13 \\
\hline
\end{tabular}

Source: SPDC, Annual Review 2000 
Currently, in Pakistan, nearly 20 per cent of the working age population is un/under-employed, which equals an open unemployment rate of 10.5 per cent. 42 per cent of the population in Pakistan is under 15 years of age. The Government response to combat this state of affairs, has focused on addressing the three different types of poverty:

- Income: through employment generation in small and medium enterprise sectors and energy;

- Consumption: through social safety net projects; and

- Basic needs: through the Local Government Plan 2000.

All three types of poverty are inter-linked and the government has included components related to infrastructure, social sector and gender in its investment plans. The Three Year Development Programme 2001-4 includes: (i) Pro-poor economic growth and employment generation (ii) Access to Micro Credit (iii) Improved Governance (iv) Physical Infrastructure through the Khushal Pakistan Programme (v) Access to Basic Services (vi) Social Safety Nets (vii) Attention to gender and minorities issues.

Employment, the key instruments of poverty alleviation, was greatly affected by the macro economic environment in the country. The Government in order to address the employment crisis is focusing on: (i) Small and Medium Enterprises as they account for 75 per cent of the manufacturing sector and have been a significant factor in the creation of employment in other countries. (ii) Agricultural Sector Reforms (iii) Overseas Employment, (iv) Infrastructure and Employment Creation. This is in recognition of the fact that employment elasticities are highest in small scale manufacturing and construction. In order to create employment and improve infrastructure the Government embarked on the Integrated Small Public Works (Khushal Pakistan) Programme in 1999. In this programme 92 per cent of the funding was allocated to the provinces and 8 per cent to Federal Areas. It was decided that 40 per cent of the district allocation would be spent on labour intensive farm to market roads, 10 per cent on women and 25 per cent on marginalised areas in the district. The nature of investment included in this project was: farm to market roads, water and sewerage, water reservoirs, solid conservation and civic amenities.

As part of the Social Safety Net Projects the Government of Pakistan has the Zakat and Ushr System which disburses Rs. 500 per month to 2 million people and the Food Support Programme which gives food subsidy of Rs. 500 to 1.2 million people. Given the extent of poverty in the over 50 years bracket, the Government has included a commitment to improve the 
management of pension funds. The existing Employees Old-Age Benefit Institution (EOBI) has a limited coverage. The Zakat fund has Rs. 20 billion in reserve. Social security coverage is limited to 0.7 million workers for benefits estimated at around Rs. 1.5 billion through Employees Social Security Institutions in Punjab and Sindh. According to a recent study indigenous philanthropy contributed an estimated Rs. 70 billion in 1998 to social welfare.

For social sectors - and basic needs poverty related to education, health, population welfare and water and sanitation - the main instrument continued to be the Social Action Programme. The SAP was started in 199293 by the Government with a view to (a) improving allocations to the social sectors as a proportion of public sector expenditure (b) focus on primary health, primary education, population welfare and community based water supply and sanitation. The focus of the donor supported SAP project for the past decade has been on these sectors and issues with some improvement in social sector spending indicators. However, the SAP focused on the rural sector at a major cost to the urban sector, particularly the urban poor. It had to be complemented by other projects which have an emphasis on nutrition, scholarship schemes for the poor, and gender (Micro credit, Crisis Centres, Skill Development Centres, Fund for Women in Distress and Detention and Community Initiatives).

Donor agencies began to support SAP after a year of its implementation by the Government of Pakistan under donor funded projects SAP I and SAP II. In addition, a major donor supported project for community infrastructure and micro credit was started in 1999 by the name of 'Pakistan Poverty Alleviation Fund'. This project will disburse nearly $\$ 90$ million to NGOs to build community infrastructure. However, the experience of the nineties suggests that effective service delivery, and not resource allocation, is the main issue to be addressed to overcome the social deficit in Pakistan. The issue, so to speak, is one of local rights.

In order to address the main issue of access to basic social services by the poor, the Government has undertaken an ambitious task of the establishment of local governments with an entirely new administrative structure. On August 14, 2000 the Local Government Plan 2000 was announced. This plan:

i. Reiterates the responsibility of the State to deliver municipal services to the rural areas. Specifically the government will remove the ruralurban divide and have disbanded existing district councils and urban local councils. 
ii. Provides a new set of institutions which will be responsible for planning of services in an entire District Government, Tehsil Municipality and Union Councils;

iii. Ensures representation of women at 33 per cent;

iv. Recognises the role of local level community organisations: Village Councils and Citizen Community Boards and information access to the public;

v. Envisages government administration (line departments, policy and judiciary) to be managed by an elected head of the District; and

vi. Allows District governments to receive money from the provinces on the basis of a financial transfer and will have the right to raise taxes at the district level.

After the implementation of the Local Government Plan the Government will have to revisit all the projects which are delivering basic municipal services and are involved at the local level. It is anticipated that the Integrated Small Works Project and the Social Action Programme Project will be redesigned under this Plan. Provincial Finance Commissions will be instituted to apportion Provincial-Local resources according to socially desirable criteria.

The strategy to address poverty has not focused on asset redistribution. It has also not focused on controlling the cost of basic services or utilities for the poor. The focus continues to be on macro economic instruments prescribed by international agencies and a high reliance on market and community based mechanisms, propagated by international agencies, for the delivery of basic needs. Independent civil society and citizen groups, working in isolation from government mechanisms, with high dependence on external financing continue to be the only 'independent' voices in the socio-economic arena. Independent research and analysis of the socio-economic sectors remains highly limited.

\section{(b) Health}

Women, children, and the rural poor carry a disproproportionate amount of the country's health burden. Nationally, provincially, and regionally, variations in the quality of service by income groups are very high and contrary to popular perception both rich and poor households, pay for health services. Drug addiction, the use of pan and tobacco are a major health burden on the country. One in five men use pan and/or tobacco on a regular basis. In the elderly the most common ailment is impaired hearing 
followed by missing limbs (10\%) and blindness (15\%). In urban areas only 25 per cent of people and in rural areas 12 per cent have corrective lenses. Children under five years of age have an average of four accidents a year requiring expert attention.

The health sector is characterised by three main types of health care: promotive; preventive; and curative. In a developing country with limited resources the focus of the health strategy should be on addressing gaps in promotive health care, preventive health care (primary health care); and in focusing on those aspects of curative health care that result from a violation of human rights. The major causes of deaths amongst women continue to be related to promotive and preventive health care for pregnancy; for children it continues to be nutrition, diarrhea and ARIs with no differential between boys and girls; and for the rural population the major issue remains access to health care.

Access to health care is impaired by the increasingly reduced role of government agencies and the associated rise in the private sector. 35 percent of the visits of rural females to health care providers are to private doctors. In all other groups private doctors provide between 45 and 65 percent of care. The growth in health care for profit has meant that the problem of physical access to health care providers for the rural population has increased.

The magnitude of malnutrition continues to be immense. One in every third child is malnourished in Pakistan. There is no gender differential in this. The overall availability of food items during 1999-2000 improved by 0.93 per cent compared to 1998-99. The per capita availability of wheat remained the same, rice and animal products improved (thus showing an aggregate improvement over the preceding year), and pulses, edible oil, fruit, vegetable and sugar decreased significantly. Although protein availability only declined marginally the overall caloric supply of food items (essential food) decreased from 2815 to 2708 calories. However, the ability of the poor to purchase food has diminished considerably in the same period. The result of this is clear in the National Health Survey of Pakistan: more than " 35 per cent of children under five years of age are short for their age, over 10 per cent are underweight for their height, and over half are anemic. Comparing these results with earlier surveys show little evidence of improvement over the last 20 years. Above 20 per cent of adults are underweight or severely thin, and about 40 per cent of women of childbearing age are anemic." More adult women are anemic than men and anemia is more common in households with a low income status. 
The Government has responded to this crisis by introducing a Food Support Programme and by undertaking promotive and preventive measures such as social marketing, improvements in technology used and regulation of market providers. This has included a focus on iodine deficiency, anemia control and breastfeeding. An evaluation of the IDD Control Programme shows that it has resulted in 73 per cent processors iodizing 35 per cent of the salt, 87 per cent of samples were adequately iodized and 79 per cent of the processors are using improved method of iodization. This has been largely due to strategies related to social marketing and improved regulation. The promotional programme on breastfeeding has been continued. The Breastfeeding Ordinance is being finalised which will regulate infant formulae available in the market. A media campaign to promote breastfeeding is underway.

More than 50 per cent of babies between 12-23 months in Pakistan are in danger of dying or incurring a serious illness or lifetime deformity because of lack of basic immunisation against six major diseases. Of major concern is the fact that in Punjab and Balochistan immunisation coverage has actually deteriorated in 1998-99. Immunisation shows no clear relationship with income levels, but is substantially higher in urban areas, thus indicating that it is possibly affected by knowledge and access. Across Pakistan private sector facilities for immunisation were within a $2 \mathrm{~km}$ reach of 60 per cent of the population compared to government facilities which were within the same distance for 55 per cent. In the early 90s the Government had targeted that by the end of SAP-I 90 per cent of these babies would be immunised. The Government's ability to deliver routine immunisation has deteriorated. Programmes implemented by the Federal Government, with the support of the military machinery, have had to be launched.

The major killer of children in Pakistan continues to be diarrhea and pneumonia. Both can be prevented through appropriate public and environmental health programmes and primary health care. Major causes of diarrhea are unsafe sanitation, and cause of death is avoided through timely administration of ORS, and drinking water. Between half and three quarters of the episodes of diarrhea are not treated with ORS. The proportion of children under five who have suffered from diarrhea in the past 30 days has decreased to 12 per cent. This is possibly due to an improvement in health promotion and awareness raising.

\section{(c) Water and Sanitation}

Nearly 50 per cent of Pakistanis today do not have a toilet. This number is as high as 63 per cent for rural households. Punjab has the poorest coverage and Balochistan the most. Moreover, 68 per cent of rural 
households do not have access to a drainage system; this coverage is the poorest for Balochistan and the highest for the Punjab. Nearly 63 per cent of the households do not have any municipal garbage collection service.

Although for drinking water overall coverage is better, this is only because of the high dependence on underground water and handpumps. These provide 57 per cent of the coverage, 60 per cent of which are installed by households themselves. This figure has not shown any change since the mid 90s.

Given that the government is the main service provider for piped water it is not surprising that the poorer households have the poorest source and furthest distance for accessing drinking water. 93 per cent of all piped schemes are installed by the Government. According to the Pakistan Integrated Household Survey (1998-99) 67 per cent of the people in the lowest income bracket in urban areas have no access to a sanitation system; 28 per cent have access to open drains and 4 per cent to underground drains as compared to the highest income bracket where 14 per cent have access to underground drains and 34 per cent to open drains. Major differences also exist between the provinces in quality and level of sanitation service. 56 per cent of the poorest households and 75 per cent of the richest households pay for water. A substantially higher proportion of urban households pay for water.

In water supply and sanitation the Government estimates that in 1999-2000 it has provided an additional 1.25 million people in urban areas and 1.75 million people in rural areas with water. It has also served an additional one million people in urban areas and 90,000 people in rural areas with sewerage services. In rural areas, of 8,404 schemes 1,968 schemes have been transferred to communities. The Government is continuing with major development schemes only in large cities. The focus remains on scheme completion and community management for 2000-1.

\section{(d) Reproductive Health}

For women the main killer continues to be complications at the time of pregnancy ie the delivery of pre and post natal care. The lifetime risk of dying from pregnancy related causes was one in 53. Only, one in three mothers went to a doctor during pregnancy and 39 per cent received post-natal care ie tetanus injection; this attendance was higher in urban areas and in the Punjab. In rural Pakistan nearly 45 per cent went to government hospitals/clinics, 22 per cent to private hospitals and clinics and 11 per cent to Traditional Birth Attendants (TBAs). 
In 1998-99 only 18 per cent women were able to give birth under medical supervision of which more were able to use private hospitals and clinics. 82 per cent women gave birth to their children at home. Nearly one-fifth of the women at the time of birth only received assistance from family members. 45 per cent received assistance from trained dais and 19 per cent from traditional birth attendants. In the 1990s improvements in the training of TBAs has improved the quality of care at birth that mothers received. However over half of the richer women in urban areas had access to doctors.

There was no decline in the 1990s in the number of women who are married in the 15-19 age group although there was some decline in the urban areas in the 20-24 age group. Almost all married women were aware of basic family planning methods with radio as the main media source; Balochistan had the lowest awareness level. This however, did not mean that they were able to exercise their right to family planning. Since the mid $90 \mathrm{~s}$ there has been only a 2 per cent increase in the number of women using family planning bringing the total to 23 per cent. Interestingly, no relationship with income was found although there is a direct correlation with education. The reason given by women for not exercising family planning were, in order of priority, desire for more children, religious reasons (which indicates low awareness levels), and spouse.

Nearly all women were satisfied with their family planning method. This could possibly be due to the fact that the methods most commonly used are tubal ligation, condoms and IUDs. The government remained the main source of supply - 51 per cent - with almost all women satisfied with the quality of service. Nearly 70 per cent of users were within a $5 \mathrm{~km}$ round trip of the family planning service. The improvements with reproductive health have also possibly led to an improvement with infant mortality. This has come down to 89 per 1000 births since 1990-91.

Overall the government has been able to address only some of the major health indicators in the $1990 \mathrm{~s}$, health here defined broadly to include public and reproductive health as well. In the year 2000 no major trends and changes were seen in the health sector. The three areas in the health sector where a major positive impact has been demonstrated in the 1990 s - and has continued in 2000- are the reproductive health programmes, control of child diarrhea and reduction in infant mortality. The government has been less successful in tackling the major issue of malnutrition and pre and post natal medical care for women. The government has also not been successful in addressing the problem of increasing deficiency in environmental and public health, particularly children's deaths due to pneumonia. 
The ability of the government to reach its citizens is evident in its basic health programme. In 1999-2000 BHUs only treated 3 per cent of all cases in rural Pakistan and the number of people that government facilities have treated since the mid $90 \mathrm{~s}$ has not changed. The under-utilisation of the government's basic health facilities can only be addressed by ensuring local level decisions. This under-utilisation is due to inappropriate levels of service for citizens (especially as private facilities offer a menu of services with an ensured basic quality and staff courtesy), non-attendance by medical practitioners, and insufficient stocks. Only 55 per cent of BHUs reported a stock of contraceptives and 79 per cent reported antibiotics.

Major reforms required in the health sector are:

i. The role of the federal government. As health is a provincial subject, provincial governments do not fully coordinate with the federal ministry.

ii. Coordination between the ministries and departments responsible for this work. This includes two aspects

- The need to have an integrated approach to health. This includes integrating promotive and preventive health, including environmental and public health, with reproductive and curative health. For example, diarrhea and/or malaria control can not be undertaken without coordination with the water and sanitation sector.

- The cost of delivery of certain programmes and projects has increased. This is due to the fact that there has been an unnecessary proliferation of parallel programmes run by different ministries like the Lady Health Worker Programme and the Village Based Family Health Workers.

iii. The need to ensure the local level service delivery. The need to localise decisions related to service delivery and their management.

iv. The need to focus on improved preventive and promotive aspects of health. Although resource allocation in the government's programmes has shifted in favour of preventive health services routine immunisation programmes of the government show serious signs of deterioration. 
v. Reach out to women and children. Ensure that female staff in health facilities increase. Some 28 per cent of government health facilities have no female staff.

vi. Ensure that the poor have basic access to health service regardless of their ability to pay, in particular, the price of medicines.

vii. The need to focus on urban health care with an emphasis on public health in intermediate and small cities as well.

viii. Focus on regulation of private sector.

\section{(e) Education}

Education is key to economic growth, improving people's opportunities and income earning power, and the successful implementation of other programmes. Education at different levels - primary, secondary, higher - and of different types - vocational and religious - plays a different role in the nation's development process.

The country faces major structural problems in the education sector today. These include:

i. The role of the federal government in a provincial function.

ii. The relationship between education and employment opportunities

iii. Access of women to education

iv. High drop out rate of school going children

v. A large unregulated informal sector - both private and religious

vi. Universities - quality and governance issues.

These issues are evident in the education indicators that Pakistan has: Literacy ratio of population under 10 years of age 45 per cent (male $56 \%$ and female $32 \%$ ); in 1981 it was 26 per cent. There are 8 million out of school girls. Almost all the poor are illiterate. There are 50.05 million illiterate people who are above 10 years of age; women are by far the higher proportion of this (142\% of male); and most of these people live in rural areas. 
The Government of Pakistan also launched a new Education Action Plan. The plan sets out compulsory primary education for all as a target. This target is to be met through:

- 29/52 billion of the budget allocated to construction of school buildings. 0.8 billion is to be spent on teacher training with the main portion of that allocated to the construction of hostels.

- 90,000 new schools without buildings would be established in addition to the new schools with buildings (8504 schools) at a cost of Rs.8.6 billion

- enrollment in Universities would be doubled in 3 years.

- reforming the countries 22 examination boards.

- Rs. 50 million on a National Education Assessment System

The main issues in the primary education area are the lack of qualified teachers and the availability of quality teaching materials. In terms of governance the issues continue to be wholesale corruption and school maladministration. There are nearly 20 per cent ghost schools, which amounts to nearly 32,000 schools. In higher education the main issues are lack of qualified university teachers, rather than buildings or equipment. There is a need to reform curricula, examinations, and school text books. Poor testing procedure, excessive memorisation and widespread cheating need to be controlled.

Universities are funded by the federal government while they are administratively under the control of the provincial governments. They are faced with serious administrative problems, large budget deficits, an outmoded curricula, a defective examination system, and a lack of focus on research. Higher education is mostly traditional and obsolete lacking simultaneously the research potential. Updation is needed to keep pace with advancement at the international level. Capacity building of local universities to start research programmes in modern technologies in collaboration with universities of international repute requires more efforts.

\section{(f) Shelter}

Pakistan is signatory to a number of international conventions which include "adequate shelter" provision as a right. This has been included in the United Nations Vancouver Declaration on Human Settlements (1976) and at the Habitat Conference. These include conventions such as the CEDAW, 
CRC, CPRMW. The housing and shelter sector is currently faced with the following problems:

- Evictions of people living on their land.

- Small Size Residential Plots

- Housing Backlog

In order to address this problem a Task Force on katchi abadis, Upgrading and Urban Renewal was set up. Key aspects of the Task Force's recommendations are: "The Government of Pakistan recognises that katchi abadis, low/under- serviced areas and areas requiring urban renewal and upgrading are a reality, an integral part of the urban and national economies, and have emerged in response to the state's inappropriate planning and provision of services for the urban poor... There is a need, at this stage, to adopt realistic policies and strategies to address both the regularisation and upgrading challenge, and, the shortfall in land and housing for the urban poor. In order to address the magnitude of the problem the government will adopt short, medium and long term measures that do no rely on ad hoc initiatives - both regarding evictions and upgrading - but address systemic constraints and problems that the urban poor face in accessing land and housing services."

The policy principles include:

i. The need to build on previous and ongoing work undertaken for the regularisation and improvement of katchi abadis and the provision of services to low/under- serviced areas; strongly discourage future encroachment and squatting on public or private land through enforcement of all existing laws in this regard; support facilitation of services to existing katchi abadis, low/under-serviced settlements and areas requiring urban renewal and upgrading;

ii. The need to facilitate an environment of mutual cooperation, responsibility and long term resolution to address the issue of land, housing and infrastructure services for the urban poor;

iii. The government reiterates its commitment to expediting the process of regularisation of katchi abadis as per the $23^{\text {rd }}$ March 1985 policy and integration of katchi abadis in the city planning and service delivery systems. In order to facilitate the regularisation of katchi abadis process - as per the $23^{\text {rd }}$ March 1985 policy - the 
government will undertake regularisation on a self-financing basis and will remove all major anomalies and discrepancies in the policy;

iv. An appropriate resettlement policy for people living without tenure on state land, needs to be formulated. No evictions of people living on state land without tenure will be undertaken till the formulation and implementation of such a resettlement policy;

v. A strategic plan, through a process of consultation with the citizens at the city level, will be formulated for urban areas. This plan will include all areas regardless of tenure and administrative jurisdiction;

vi. Transparency and information access on land, housing and services for the citizens of Pakistan will be ensured. The government will ensure changes in ordinances related to information access and the acquisition and sale of land; and

vii. Major investments, in land, housing and services, will only be undertaken after extensive public consultation and enquiry at the city level.

The Government of Pakistan allocated Rs 4 billion in 1999-2000 shelter. The budget for the Physical Planning and Housing Sector (which includes water supply and sanitation) has been reduced by 15 per cent for 2000-1. The recommendations of the Task Force, if taken up, by the present government could have a major impact on the sector, especially on the key structural and systemic issues.

\section{(g) Environment}

Environment, unlike the other socio-economic sectors, is in principle a public good. Unlike other public goods it is one that transcends international boundaries and generations. It relates to the depletion of existing resources, it is a 'right' that present generations hold for the future generations. In effect, environment is perhaps one of the critical 'rights' that are based on the opportunity cost of one right over the other: primarily related to economic generation through energy and job creation for present generations at the cost of environmental degradation for future generations.

The major milestone, globally, in the environmental debate this year was the launching in November 2000 of the Dams and Development, A new Framework for Decision-Making Report by the World Commission on Dams. The recommendations of the World Commission on Dams in their Report have 
far reaching implications for the geo-politics of the region. This included of course a subject of critical importance for the federation: the Kalabagh Dam.

The Three Year Development Programme (2001-2004) will aim to achieve medium-term targets of the following three objectives:

(i) Conservation of biophysical environment for sustainability of natural resource base.

ii. Rationalisation of production processes and consumption patterns for making them least cost and least detrimental to air, water and land resources.

iii. Reduction of pollution of living and working environment to bring within National Environmental Quality Standards (NEQS).

Under the Three Year Development Programme (2001-2004), development activities in various sectors would be made environment-friendly, ensuring sustainability. This will be achieved through institutional strengthening and capacity building, public awareness and participation, effective policing i.e. enforcement of NEQS and legislation, and safeguarding environment in the development process. The Plan stresses an effective coordination among different stakeholders involved in planning, implementation, and monitoring of development programmes and projects. It also reaffirms Government's obligations under international Conventions and Protocols to participate in regional and global initiatives on environmental amelioration.

\section{Concluding Remarks}

This paper is an attempt to raise the issue of the dichotomy that exists between social and economic rights, and human rights - civil and political. Today, at the turn of a new millennium, the citizens of Pakistan can hold the State responsible for the decade long ascent in poverty; for its apathy towards arresting it; and the inability to address the fundamental structural flaws in the economy that have contributed to its increase. We can also judge the State by how it has improved basic health care, access to primary education and improved shelter options for the poor. At the end of 2000 in the health sector the State stands responsible for the inability to improve preventive and promotive health care, due not to a lack of resources but to inappropriate delivery; to reduced enrollment for primary education in the public sector, when resource allocation is on the increase; and the brutality of evicting citizens from State land without the provision of alternative shelter options. Even where 'absolute social and economic rights' are not assessed, in relative 
terms the State in Pakistan is accountable for inappropriate governance structures, apathy, negligence and callousness in the provision of social and economic services.

Policy makers, researchers and international organisations define poverty in many different terms and ways: poverty in terms of a minimum income, poverty in terms of a minimum level of consumption; poverty in terms of access to basic education, health and shelter. All these forms of poverty, or dimensions of poverty, impinge on the fundamentals of human dignity. In Pakistan all these are violated for an increasing number of its citizens.

The year 2000 also did not see any improvement on the part of civil society and citizen groups to address the issue of social and economic rights. These organisations, even when concerned exclusively with social and economic issues, continued to focus the energies on the delivery of actual services, primarily working independently of the State machinery. In a sense, both the state and civil society organisations have paid more attention to investment rather than the rights issues.

The question is: Are social and economic rights, rights anyway? Rights are claims on other individuals and collectivities and their realisation requires some mechanism to obligate other individuals or collectivities. Human rights though innate and intrinsic have nevertheless to be legislated, which makes them justiciable. There is thus recourse to law to secure claims or its threat to prevent violation. The justiciability of civil and political rights enables the human rights movement to focus on them.

However, an unemployed person, for instance, cannot go to a court of law to enforce the right to be employed, even in a society committed to full employment. The issue was vociferously debated at the time of the formulation of the of the 1973 Constitution. Some opposition members had moved to make basic human needs a justiciable fundamental right after a specified time. To this President Bhutto replied in his aide-memoire: "When we achieve our aim of establishing a socialist economy, to which you [Opposition] object, we would provide all this and more .... We shall also provide means for their enforcement in the fullness of time, but not through the writ jurisdictions of the High Courts. Your proposal would not only make the task of the High Courts impossible but would also lay insuperable obstacles in the way of the Executive for achieving the end to which it is dedicated, the welfare of the people." Article 29(3) merely provided that every year a report shall be laid before the National Assembly on the observance and implementation of the Principles of Policy. 
The fulfilment of social and economic rights requires resources. However, the availability of resources does not guarantee that such will be the case. Resource distribution is not necessarily just. Securing human rights promotes an environment of justice. But securing human rights in situations of extreme poverty, which limits the very capabilities necessary to secure all forms of rights, presents the puzzle that this paper has only begun to identify. A major new research programme will be necessary for a systematic and systemic understanding of the rights puzzle. 
42 The Lahore Journal of Economics, Vol.6, No.1

International Development Targets

Annex-I

\begin{tabular}{|c|c|}
\hline Indicators & Target \\
\hline Income Poverty & $\begin{array}{l}\text { Halving the Share of the Population living in poverty } \\
\text { from } 30 \% \text { in } 2000 \text { to } 15 \% \text { by } 2015\end{array}$ \\
\hline Extremely Poor & $\begin{array}{l}\text { Reduce the proportion of the extremely poor to } \\
12.5 \% \text { of the world population by } 2015\end{array}$ \\
\hline Illiteracy & $\begin{array}{l}\text { Reduce adult illiteracy rate between 1990-2000. The } \\
\text { target has been extended. }\end{array}$ \\
\hline Education & $\begin{array}{l}\text { Enroll all children in primary school by } 2015 \text {. To } \\
\text { ensure that, by the same date, boys and girls alike } \\
\text { will be able to complete a full course of schooling; } \\
\text { and that boys and girls will have equal access to all } \\
\text { levels of education. }\end{array}$ \\
\hline Life Expectancy & $\begin{array}{l}\text { To raise the average life expectancy to } 60 \text { years by } \\
2000 \text {. The target has been extended. }\end{array}$ \\
\hline $\begin{array}{l}\text { Infant and Child } \\
\text { Mortality }\end{array}$ & $\begin{array}{l}\text { Reduce infant and child mortality rates by two third } \\
\text { by } 2015\end{array}$ \\
\hline $\begin{array}{l}\text { Maternal } \\
\text { Mortality }\end{array}$ & $\begin{array}{l}\text { Reduce maternal mortality rate by three-quarters by } \\
2015\end{array}$ \\
\hline Malnutrition & $\begin{array}{l}\text { Reduce by half the proportion of children under five } \\
\text { who are under-weight by } 2000 \text {. The target has been } \\
\text { extended. }\end{array}$ \\
\hline $\begin{array}{l}\text { Reproductive } \\
\text { Health }\end{array}$ & $\begin{array}{l}\text { Provide access for all who need reproductive health } \\
\text { services by } 2015\end{array}$ \\
\hline Environment & $\begin{array}{l}\text { Implement national strategies for sustainable } \\
\text { development by } 2005 \text { so as to reverse the loss of } \\
\text { environment resources by } 2015\end{array}$ \\
\hline Gender Equality & $\begin{array}{l}\text { Promote gender equality and the empowerment of } \\
\text { women, as effective ways to combat poverty, hunger } \\
\text { and disease and to stimulate development that is truly } \\
\text { sustainable }\end{array}$ \\
\hline
\end{tabular}


Safety Nets Provide special assistance to the marginalised and the vulnerable.

HIV/AIDS Have by 2015 halted, and begin to reverse, the spread of HIV/AIDS, the scourge of malaria and the major diseases that afflict humanity

Productive Work Develop and implement strategies that give young people everywhere a real chance to find decent and productive work

Source: Government of Pakistan, Planning Commission. Three Year Poverty Reduction Programme, 2001-4. Islamabad. 
44 The Lahore Journal of Economics, Vol.6, No.1

Covenants and Charters: Pakistan's Position

Annex-II

(S = Signed, N = Not Signed)

\begin{tabular}{ccc}
\hline Covenants and Charters & $\begin{array}{c}\text { Pakistan's } \\
\text { Position }\end{array}$ & $\begin{array}{c}\text { Related National Policies/ } \\
\text { Departments or Institutions } \\
\text { Responsible }\end{array}$ \\
\hline
\end{tabular}

\section{General}

International Covenant on $\mathrm{N}$ Principles of Policy as

Economic, Social and Cultural enshrined in the Constitution

Rights, 1966

Convention on the suppression S

of the traffic in persons, 1950

Convention related to the Status N

of Refugees, 1951

International Convention on $\mathrm{S}$

Due Elimination of all Forms of

Social Discrimination

International Convention on the

$\mathrm{N}$

Protection of the Rights of all

Migrant Workers and Members

of their Families

\section{Employment}

Hours of Work (Industry S Ministry of Labour Convention), 1919

Night Work (Women) S - do -

Convention, 1919

Night Work of Young Persons S

(Industry), Convention 1919

Right of Association (Agriculture) S

Convention, 1921 
$\begin{array}{lr}\text { Weekly Rest } & \text { Ronvention, } \\ \text { Co21 }\end{array}$

Minimum Age (Trimmers and Stokers) Convention, 1921

Workmen's

Compensation

(Occupational

Diseases),

Equality of Treatment (Accident Compensation), Convention 1925

Inspection of Emigrants

Convention, 1926

Making of Weights (Packages

Transported by Vessels)

Convention, 1929

Forced Labour Convention, S 1930

Protection against Accidents (Dockers) Convention (Revised), 1937

Underground work (women) S Convention, 1935

Minimum Age (Industry) S Convention (Revised), 1937

Final Articles Revision Convention, 1946

Labour Inspection Convention, 1947

Freedom of Association and Protection of the Right to Organise Convention, 1948

- do -

- do -

- do -

- do -

- do -

- do -

- do -

- do -

- do -

- do -

- do -

- do -

- do - 
The Lahore Journal of Economics, Vol.6, No.1

$\begin{aligned} & \text { Night Work (Women) } \\ & \text { Convention, } 1948\end{aligned}$
$\begin{aligned} & \text { Night Work of Young Persons } \\ & \text { (Industry) Convention (Revised), } \\ & 1948\end{aligned}$
$\begin{aligned} & \text { Right to Organise and Collective } \\ & \text { Bargaining Convention, } 1949\end{aligned}$
$\begin{aligned} & \text { Abolition of Forced Labour } \\ & \text { Convention, } 1957\end{aligned}$
$\begin{aligned} & \text { Weekly Rest (Commerce and } \\ & \text { Offices) Convention, } 1957\end{aligned}$
$\begin{aligned} & \text { Indigenous and } \quad \text { Tribal } \\ & \text { Populations Convention, } 1957\end{aligned}$
$\begin{aligned} & \text { Discrimination (Employment and } \\ & \text { Occupation) Convention, } 1958\end{aligned}$

Final Articles Revision S

Convention, 1961

Equality of Treatment (Social S

Security) Convention, 1962

Tripartite Consultations (In S

ternational Labour Standards)

Convention, 1976

Vocal Rehabilitation and S

Employment (Disabled Persons)

Convention, 1983

Health and Reproductive Health

International Conference on

Population and Development

S (ICPD), 1994

a. Access to education, especially for girls 
b. Reduced mortality rates

c. Increased access to quality reproductive health services, including family planning.

Universal access to family planning no later than 2015 .

Health for All (WHO)

S Ministry of Health

\section{Education}

Jomtein Conference, $1990 . \quad$ S Ministry of Education

Education for All

Dakar Declaration, 2000. Education for All

\section{Shelter}

$\begin{array}{lrrl}\text { United Nations } & \text { Vancouver } & \text { S } & \begin{array}{l}\text { National Policy on Katchi } \\ \text { Declaration on }\end{array} \\ \text { Settlements, } 1976 & \text { Human } & & \begin{array}{l}\text { Abadis, Upgrading and Urban } \\ \text { Renewal, 2000 }\end{array}\end{array}$

Women and Children

Convention on the Elimination

S Ministry of Women of all forms of discrimination against women, 1979

Convention on the Rights of the Child, 1989

S Ministry of Women Social Welfare

To translate into national and provincial laws and programmes:

- Protected against all forms of discrimination

- Ensure to the maximum extent possible the survival and development of the child 
- Right to be protected from economic exploitation

The Platform for action at the Fourth World Conference on S Ministry of Women Women (FWCW), Beijing 1995 Development

Maternity Protection Convention $\mathrm{N}$ (revised)

Equal Remuneration Convention 1951

Ramsar Convention

S Ministry of Environment

Framework Convention on Climate Change

Convention on Biodiversity

S

Agenda 21

S

Rio Declaration

S

International Plant Protection Convention, Rome 1951

S - do -

Plant Protection Agreement for

S PARC, Ministry of Agriculture the South East Asia and Pacific Region, Rome 1956

Convention for the Protection of World Cultural and Natural Heritage (World Heritage Convention), Paris, 1972

Convention on International

S Inspector General Forest, Trade in Endangered Species of Wild Fauna and Flora (CITES), Washington, 1973

Convention on the Conservation of Migrating Species as Wild Animals, Bonn, 1979

S Pakistan National Commission for UNESCO Ministry of Environment, Local Government and Rural Development

S Inspector General Forest, Ministry of Environment, Local Government and Rural Development 
Convention on the Law of the Sea, Montego Bay, 1982

Vienna Convention for the Protection of Ozone Layer, Vienna, 1985

Montreal Protocol on Substances that Deplete the Ozone Layer, Montreal, 1987 and amendments thereto

Agreement on the Network of Aqua Culture Centres in Asia and the Pacific, Bangkok, 1988

Convention on the Control of Trans-boundary Movement of Hazardous Waste and its Disposa1, Base1, 1989

Convention on Biological Diversity, Rio de Janerio, 1992

United Nations Framework Convention on Climate Change, Rio de Janeiro, 1994

South Asia Cooperative Environment Programme (SACEP)

Commission on Sustainable Development (CSD)

Global Environment Facility

UN Convention to Combat Desertification (CCS) ratified in 1997
S National Institute of Oceonography, Karachi

S Ministry of Environment, Local Government and Rural Development

S Ozone Cell, Ministry of Environment, Local Government and Rural Development

S Ministry of Environment, Local Government and Rural Development

S Ministry of Environment, Local Government and Rural Development

S Ministry of Environment, Local Government and Rural Development

S Ministry of Environment, Local Government and Rural Development

S Ministry of Environment, Local Government and Rural Development

S Ministry of Environment, Local Government and Rural Development

S Ministry of Environment, Local Government and Rural Development

S Ministry of Environment, Local Government and Rural Development 
50 The Lahore Journal of Economics, Vol.6, No.1

Human Development Index

Annex III

\begin{tabular}{lcccc}
\hline & Pakistan & India & Tajikistan & $\begin{array}{c}\text { Average of } \\
\text { Medium HD } \\
\text { Countries }\end{array}$ \\
\hline $\begin{array}{l}\text { Life expectancy at birth } \\
\text { (years) }\end{array}$ & 64.4 & 62.9 & 67.5 & 66.9 \\
$\begin{array}{l}\text { Primary, secondary, } \\
\text { tertiary enrolment (\%) }\end{array}$ & 43.0 & 54.0 & 69.0 & 65.0 \\
$\begin{array}{l}\text { GDP per capita (\$ PPP) } \\
\text { Adult literacy rate (\% }\end{array}$ & 1,715 & 2,077 & 1,041 & 3,458 \\
age 15 and above) & 44.0 & 55.7 & 99.0 & 76.9 \\
$\begin{array}{l}\text { Life Expectancy Index } \\
\text { Education Index }\end{array}$ & 0.66 & 0.63 & 0.71 & 0.70 \\
$\begin{array}{l}\text { GDP Index } \\
\text { Human Development }\end{array}$ & 0.44 & 0.55 & 0.89 & 0.73 \\
Index value & 0.47 & 0.51 & 0.39 & 0.59 \\
$\begin{array}{l}\text { Human Development } \\
\text { Index rank }\end{array}$ & 135 & 0.563 & 0.663 & 0.673 \\
\hline
\end{tabular}

Source: $\quad \mathrm{UNDP}$, Human Development Report, 2000 
The Challenge Ahead

Annex-IV

\begin{tabular}{|c|c|c|c|c|}
\hline \multirow[t]{2}{*}{ Indicators } & \multirow[t]{2}{*}{ International Target } & \multicolumn{3}{|c|}{ Pakistan Scenario } \\
\hline & & 2001 & 2004 & 2015 \\
\hline \multicolumn{5}{|c|}{ Poverty and Employment } \\
\hline $\begin{array}{l}\text { Income } \\
\text { Poverty }\end{array}$ & $\begin{array}{l}\text { Halving the Share of } \\
\text { the Population living } \\
\text { in poverty from } 30 \% \\
\text { in } 1999-2000 \text { to } 15 \% \\
\text { by } 2015\end{array}$ & $\begin{array}{l}\text { Rs. } 24,000 \\
\text { per capita }\end{array}$ & $\begin{array}{l}\text { Rs. } 27,000 \\
\text { per capita per } \\
\text { annum. }\end{array}$ & Rs. 44,000 \\
\hline $\begin{array}{l}\text { Extremely } \\
\text { Poor }\end{array}$ & $\begin{array}{l}\text { Reduce the } \\
\text { proportion of the } \\
\text { extremely poor to } \\
12.5 \% \text { of the world } \\
\text { population by } 2015\end{array}$ & $\begin{array}{l}\text { Absolute } \\
\text { poverty in } \\
\text { terms of food } \\
\text { inadequacy is } \\
30 \%\end{array}$ & $\begin{array}{l}\text { Absolute } \\
\text { poverty in } \\
\text { terms of food } \\
\text { inadequacy } \\
\text { will be } \\
\text { reduced to } \\
25 \%\end{array}$ & $10 \%$ \\
\hline $\begin{array}{l}\text { Productive } \\
\text { Work }\end{array}$ & $\begin{array}{l}\text { Develop and } \\
\text { implement strategies } \\
\text { that give young } \\
\text { people everywhere a } \\
\text { real chance to find } \\
\text { decent and } \\
\text { productive work }\end{array}$ & $\begin{array}{l}\text { Unemploy- } \\
\text { ment } 10.4 \%\end{array}$ & $\begin{array}{l}\text { Unemploy- } \\
\text { ment reduced } \\
\text { to } 10 \%\end{array}$ & $68 \%$ \\
\hline Safety Nets & $\begin{array}{l}\text { Provide special } \\
\text { assistance to } \\
\text { marginalised and } \\
\text { vulnerable peoples }\end{array}$ & $\begin{array}{l}\text { Zakat } \\
\text { reaching out } \\
\text { to } 3 \text { million } \\
\text { persons }\end{array}$ & 4 million & \\
\hline \multicolumn{5}{|c|}{ Health and Reproductive Health } \\
\hline Malnutrition & $\begin{array}{l}\text { Reduce by half the } \\
\text { proportion of } \\
\text { children under five } \\
\text { who are under } \\
\text { weight by } 2000\end{array}$ & $\begin{array}{l}39 \% \text { of } \\
\text { children } \\
\text { under } 5 \text { are } \\
\text { malnourished }\end{array}$ & $\begin{array}{l}35 \% \text { of } \\
\text { children } \\
\text { under } 5 \text { will } \\
\text { be } \\
\text { malnourished }\end{array}$ & $20 \%$ \\
\hline
\end{tabular}


52 The Lahore Journal of Economics, Vol.6, No.1

Health

EPI Targets

Water and

Sanitation

Life

Expectancy

To raise the average life expectancy to 60 years by 2000

Infant and

Child

Mortality

Maternal

Mortality

Reduce infant and

child mortality rates

Reduce maternal
$70 \%$ of all

$95 \%$

citizens will

have access to

health

services

Overall

$100 \%$

coverage of 6

major

vaccines to

$90 \%$

Reduction of

$100 \%$

Measles by

$80 \%$

$63 \%$ of all

$66 \%$ of all

$92 \%$

citizens have citizens have

access to

access to

clean drinking clean drinking

water $183 \%$ in water $(86 \%$ in

urban area; urban areas;

$53 \%$ in rural $56 \%$ in rural

areas) (this

areas)

figure is

different in

diff. parts of

the doc)

62.9 year

64.4 years

69 years

90 per 1000

65 per 1000

30

live births

live births

by two third by 2015

400 by

300 by

180 mortality rate by three-quarters by 2015
100,000 live 100,000 live births 
Low Birth

$25 \%$

$20 \%$

$12 \%$

Weight Babies

$\begin{array}{ll}\text { Reproductive } & \begin{array}{l}\text { Provide access for all } \\ \text { who need } \\ \text { reproductive health } \\ \text { services by } 2015\end{array} \\ \text { HIV/AIDS } & \begin{array}{l}\text { Have by } 2015 \text { halted, } \\ \text { and begun to reverse, } \\ \text { the spread of } \\ \text { HIV/AIDS, the } \\ \text { scourge of malaria } \\ \text { and other major } \\ \text { diseased that afflict } \\ \text { humanity }\end{array}\end{array}$

Reduction on

Neo-Natal

Tetanus by

2002

\section{Education}

$\begin{array}{lllll}\text { I1literacy } & \begin{array}{l}\text { Reduce adult } \\ \text { illiteracy rate }\end{array} & \text {-Adult literacy } & \begin{array}{l}\text { Adult literacy } \\ \text { increased to }\end{array} & 84 \% \\ \text { between 1999-2000 } & \text {-Female } & 61 \% & \\ & \text { literacy rate } & 47 \% & 76 \% \\ & 39 \% & 73 \% & \\ & \text {-Male literacy } & & \\ & \text { rate 64\% } & \end{array}$


54 The Lahore Journal of Economics, Vol.6, No.1

\begin{tabular}{|c|c|c|c|}
\hline Education & $\begin{array}{l}\text { Enroll all children in } \\
\text { primary school by } \\
2015 \text {. To ensure } \\
\text { that, by the same } \\
\text { date, children boys } \\
\text { and girls alike will be } \\
\text { able to complete a } \\
\text { full course of primary } \\
\text { schooling; and that } \\
\text { girls and boys will } \\
\text { have equal access to } \\
\text { all levels of } \\
\text { education. }\end{array}$ & $\begin{array}{l}\text { Primary } \\
\text { enrolment } \\
\text { Total } 83 \% \\
\text { Boys } 96 \% \\
\text { Girls } 70 \%\end{array}$ & $\begin{array}{l}\text { Total } 94 \% \\
\text { Boys } 102 \% \\
\text { Girls } 85 \%\end{array}$ \\
\hline
\end{tabular}

\section{Women and Children}

$\begin{array}{ll}\text { Gender } & \text { Promote gender } \\ \text { Equality } & \text { equality and the } \\ \text { empowerment of } & \text { women, as effective } \\ & \text { ways to combat } \\ \text { poverty, hunger and } \\ \text { disease and to } \\ \text { stimulate } \\ \text { development that is } \\ \text { truly sustainable }\end{array}$

\section{Environment}

$\begin{array}{ll}\text { Environment } & \begin{array}{l}\text { Implement national } \\ \text { strategies for }\end{array} \\ & \text { sustainable } \\ & \text { development by } 2005 \\ & \text { so as to reverse the } \\ & \text { loss of environment } \\ & \text { resources by } 2015\end{array}$

Air Pollution

$\begin{array}{ll}50 \% \text { of } & 60 \% \text { will not } \\ \text { population is } & \text { be affected by } \\ \text { affected by air } & \text { morbidity } \\ \text { pollution } & \begin{array}{l}\text { producing } \\ \text { affects of air } \\ \text { pollution }\end{array}\end{array}$


Pervez Tahir and Sara Fatima 55

$\begin{array}{ll}\text { Planned } & 43 \% \text { (64\% in } \\ \text { Sanitation } & \text { urban and } \\ \text { facilities are } & 31 \% \text { in rural) } \\ \text { available to } & \\ 39 \% & \end{array}$


56 The Lahore Journal of Economics, Vol.6, No.1

\section{References}

Constitution of the Islamic Republic of Pakistan 1973. Lahore.

Federal Bureau of Statistics. 2000. Pakistan Integrated Household Survey 1998-99. Islamabad.

Human Rights Commission of Pakistan. 2000. State of Human Rights 2000. Lahore.

Mahbub u1 Haq Centre for Human Development/UNDP. 2000. A Profile of Poverty in Pakistan, Islamabad.

Masood, Wajahat, 1999, Rights Poverty in Pakistan Commissioned by Swiss Agency for Development and Co-operation, Islamabad.

Ministry of Health. 1998. Health Information Management System. Islamabad.

Pakistan Medical Research Council. 1998. National Health Survey of Pakistan, Islamabad.

Planning Commission, Government of Pakistan. 2001. Three Year Poverty Reduction Programme

2001-04: Draft for Public Discussion. Islamabad.

Social Policy and Development Centre. 2000. Annual Review 2000: Towards Poverty Reduction, Karachi.

Tahir, Pervez. 1973. "Economic Aspects of Permanent Constitution." The Pakistan Times, April 16.

Also in Pervez Tahir, Pakistan: An Economic Spectrum. Lahore: Arslan Publications, 1974.

Tahir, Pervez. 2000. Environment and Development in Pakistan. LEADPakistan. Islamabad.

UNDP. 2000. Human Development Report New York: Oxford University Press. 